PART I. PHYSICAL ACTIVITY OF SOCIAL AND PROFESSIONAL GROUPS DZIAŁ I. AKTYWNOŚĆ FIZYCZNA GRUP SPOŁECZNYCH I ZAWODOWYCH

\title{
PSYCHOLOGICAL, SOCIAL AND ENVIRONMENTAL PREDICTORS OF PHYSICAL ACTIVITY IN MEXICAN ADOLESCENTS
}

\section{PSYCHOLOGICZNE, SPOŁECZNE I ŚRODOWISKOWE CZYNNIKI WPŁYWAJĄCE NA AKTYWNOŚĆ FIZYCZNĄ U NASTOLATKÓW MEKSYKAŃSKICH}

\author{
Armando Cocca ${ }^{1(\mathrm{~A}, \mathrm{C}, \mathrm{D}, \mathrm{E}, \mathrm{F}, \mathrm{G})}$, Frantisek Chmelík $^{2(\mathrm{D}, \mathrm{F}, \mathrm{G})}$, Michaela Cocca $^{1(\mathrm{~A}, \mathrm{~B}, \mathrm{D}, \mathrm{E})}$, \\ Francisco Daniel Espino Verdugo ${ }^{3(B, F)}$, Luis Tomás Ródenas Cuenca ${ }^{3(B, C, D)}$
}

\author{
${ }^{1}$ College of Education and Human Development, Texas A\&M University San Antonio, United States of America \\ ${ }^{2}$ Faculty of Physical Culture, Palacky University of Olomouc, the Czech Republic \\ ${ }^{3}$ School of Sports Organization, Autonomous University of Nuevo Leon, Mexico
}

Authors' contribution Wkład autorów: A. Study design/planning zaplanowanie badań B. Data collection/entry zebranie danych C. Data analysis/statistics dane - analiza i statystyki D. Data interpretation interpretacja danych E. Preparation of manuscript przygotowanie artykułu F. Literature analysis/search wyszukiwanie i analiza literatury G. Funds collection zebranie funduszy

\section{Summary}

Background. Sedentarism and Physical Activity (PA) are considered main components of people's lifestyle and key indicators of health. Although they can be seen as opposite life conducts that reduce each other's effects on health, no study has yet clarified the nature of their relation. However, both behaviors can be influenced by similar psychological, social, and environmental constructs.

Material and methods. We selected 480 students (272 boys, 208 girls) from middle schools in the metropolitan area of Monterrey (Mexico), who filled in questionnaires on PA behaviors and social-environmental correlates through an online system.

Results. Our outcomes highlighted overall low PA levels. Further, girls are more affected by their social environment, whereas physical environment barriers represent a fitting predictor of boys' PA. Regardless of gender, PA engagement seems to be significantly determined by the level of enjoyment of sedentary behaviors.

Conclusions. These results can help professionals in PA and health create gender-specific interventions targeting to raise youth's PA levels by means of enhancing psychosocial and contextual features. Due to the lack of studies on psychological factors related to sedentary behaviors, our results could arouse attention on this issue and promote further research to better understand the processes beneath it.

Keywords: health, exercise, youth, environment, behavior

\section{Streszczenie}

Wprowadzenie. Siedzący tryb życia i aktywność fizyczna (AF) są postrzegane jako główne elementy życia ludzi i kluczowe wskaźniki zdrowia. Chociaż można je uznać za przeciwstawne i wzajemnie wykluczające się w kontekście zdrowia, literatura nie wyjaśniła jeszcze charakteru ich relacji. Oba te style życia mogą jednakże być ukształtowane przez podobne czynniki psychologiczne, społeczne i środowiskowe.

Materiał i metody. W badaniu wzięło udział 480 uczniów (272 chłopców, 208 dziewcząt) z gimnazjów w Monterrey (Meksyk), którzy wypełniali kwestionariusze w systemie online dotyczące ich aktywności fizycznej i relacji społeczno-środowiskowych.

Wyniki. Uzyskane wyniki wykazują ogólnie niski poziom aktywności fizycznej. Ponadto, okazuje się, iż otoczenie społeczne ma większy wpływ na zachowanie dziewcząt w zakresie kultury fizycznej, podczas gdy głównym czynnikiem oddziałującym na chłopców są ich ograniczenie fizyczne. Niezależnie od płci, zaangażowanie w uprawianie aktywności fizycznej jest znacząco ograniczane poziomem zadowolenia z siedzącego trybu życia.

Wnioski. Niniejsze wyniki mogą pomóc profesjonalistom z dziedziny zdrowia publicznego i aktywności fizycznej w stworzeniu programów interwencyjnych skierowanych do poszczególnych płci, które mogłyby okazać się pomocne w podniesieniu poziomu aktywności fizycznej wśród młodzieży poprzez poprawę funkcji psychospołecznych i środowiskowych. Ze względu na brak badań nad czynnikami psychologicznymi związanymi z siedzącym trybem życia, nasze wyniki mogłyby zachęcić badaczy do podjęcia dalszych prac, mających na celu lepsze zrozumienie procesów wpływających na aktywność młodzieży.

Słowa kluczowe: zdrowie, ćwiczenia, młodzież, środowisko, zachowanie
Tables: 5

Figures: 0

References: 41

Submitted: 2017 Aug 26

Accepted: 2017 Sept 20

Cocca A, Chmelík F, Cocca M, Espino Verdugo FD, Ródenas Cuenca LT. Psychological, social and environmental predictors of physical activity in Mexican adolescents. Health Problems of Civilization. 2017; 11(3): 125-134. doi: 10.5114/hpc.2017.70524.

\footnotetext{
Address for correspondence / Adres korespondencyjny: Armando Cocca, College of Education and Human Development, Texas A\&M University, One University Way, San Antonio TX, 78224, United States of America, e-mail: acocca@tamusa.edu, phone: +12107842550

Copyright: (C) 2017 Pope John Paul II State School of Higher Education in Biała Podlaska, Armando Cocca, Frantisek Chmelík, Michaela Cocca, Francisco Daniel Espino Verdugo, Luis Tomás Ródenas Cuenca. This is an Open Access journal, all articles are distributed under the terms of the Creative Commons AttributionNonCommercial-ShareAlike 4.0 International (CC BY-NC-SA 4.0) License (http://creativecommons.org/licenses/by-nc-sa/4.0/), allowing third parties to copy and redistribute the material in any medium or format and to remix, transform, and build upon the material, provided the original work is properly cited and states its license.
} 


\section{Background}

As many reports and international statistical updates confirm, public and individual health conditions are worsening throughout time [1]. Even though there is evidence of a reduction of strokes occurrence in the last years, still the incidence in other non-transmissible diseases showed a raise of $3.2 \%$. The World Health Organization (WHO) recognizes obesity and sedentarism, spread globally regardless of socioeconomic level, culture or ethnicity, as main factors for the raising rates of heart diseases, diabetes and cancer [1]. International organizations dealing with health care, as well as many researchers in the same field, stress the fact that the consequences of obesity, physical inactivity, and sedentarism are accentuated if these problems appear in early ages $[2,3]$.

Sedentarism, which is defined as participation in low-energy-expenditure activities such as watching television or using computers and tablets, has been strongly associated with several health issues [4]. For instance, authors have demonstrated a significant relation of being inactive with mental diseases or functional somatic symptoms [5,6]. Fröberg and Raustorp found an association between sedentary behaviors and cardiometabolic risk factor profile in adults, as well as premature all-cause disease mortality [7]. Furthermore, authors found out that it could be linked to higher risk of suffering from diabetes mellitus or metabolic syndrome [8]. The high risk for health when being engaged in sedentary activities is confirmed in studies on adolescents and children, too [9]. Stone and Faulkner state that physical activity (PA) rates have been declining amongst children in recent years, as the youth are more and more engaged in sedentary activities in a home environment, such as video gaming or watching television [10].

Opposite to sedentarism, PA positively influences the structuring of a healthy lifestyle [11]. Interventions based on increasing PA levels in populations of youth could be more suitable than programs focused on changing nutritional and social habits, which can be affected by contingent variables such as parents' economical condition, social support, or participants' disposition towards keeping established conducts out of the controlled research environment [12]. A positive association between PA and health is demonstrated in many studies [13]. The effects of PA on health are stronger if it is carried out from early ages, as authors found out that active kids are more likely to keep this habit in their adulthood [14], to have lower Body Mass Index (BMI) in adulthood even if they become inactive, and to have better metabolic parameters and consequently lower risk profile for cardiovascular diseases [15]. Therefore, enhancing PA levels should represent a priority if we aim to improve health in youth, and consequently prevent this population from low quality of life and higher cardiovascular risk in their adulthood.

Though sedentarism and PA can be considered antithetical life conducts that reduce the effect of each other on people's lifestyle, some authors tend to consider them as separate elements, both having an isolated impact on health [16]. However, both behaviors are empowered or attenuated by similar psychological, social and environmental patterns $[17,18,19]$. For instance, authors have pointed out that individuals who regard exercising as important for their lives, are more likely to have higher levels of daily PA and better quality of life [20]. Vernadakis et al. suggested that when individuals consider a certain activity as enjoyable, they are more inclined to engage in it regardless of its active or sedentary character [21]. These outcomes were confirmed by Salmon et al., who found out an association between preference toward sedentary behaviors and decreased likelihood of being physically active [22]. Also, individuals' confidence to overcome specific inactive behaviors can affect their decision to engage in PA, or displace it in time [23]. As regard to social aspects of PA and sedentarism, literature confirms that persons constituting an individual's macro- and micro-community play an important role in the election of a certain lifestyle [24]. Structure and culture of the community in which a person lives can determine his/her choice of being active or engaging in sedentary habits. In addition, parents', peers', and other significants' choices and habits have a direct influence on a person's lifestyle, as he/she will tend to get involved in the same activities [25]. As Dias et al. highlight in their study on perceived obstacles towards leisure-time PA in adolescents, a common reason for not getting involved in exercise is lack of friends or company to engage in PA with [26]. Environment also appears to be a determinant for an active or sedentary life. Researchers and environmental specialists have studied many contextual antecedents of PA and inactivity. Among them, perceived barriers towards PA are considered influential variables for people to decide to be active, as well as for overall intensity and quantity of daily PA [27]. In addition, neighborhood safety is regarded as an essential characteristic for a close environment to foster active lifestyle. In fact, when the neighborhood is perceived as unsafe, youth tend to reduce time spent exercising, whereas they engage more frequently in sedentary activities such as watching television [28].

Considering the importance of reducing sedentarism at the same time as we promote increased participation in PA in youth, a necessary step for the implementation of active living programs consists of understanding the weight of psychological, social, and contextual factors that influence youth's habits. Thus, the aim of this 
research is to assess PA levels in a sample of Mexican adolescents; and to estimate psychological, environmental and social predictors of PA in boys and girls from the same sample.

\section{Material and methods}

\section{Sample}

Firstly, we selected the population for the study with a non-probabilistic technique of sampling based on convenience. The main reason for choosing this technique was the difficulty in covering all the urban areas of Monterrey both in terms of environmental and bureaucratic barriers for approaching school directive boards. Moreover, holding Internet connection and sufficient number of computers were requirements for schools to be considered for the current research, since the data collection was conducted through an on-line system. Eight middle schools were finally selected for the study. Successively, we applied a probabilistic sampling method based on random stratified selection and proportional affixation (with statistical error fixed at 2.5\%) to obtain a proportional number of participants from each grade while preserving the original composition of this population by gender, age, and school.

Finally, 480 students (272 boys, 208 girls) composed the sample. Descriptive analysis of participants is described in Table 1.

Table 1. Descriptive analysis of secondary school students included in the final sample, by gender

\begin{tabular}{|c|c|c|c|c|}
\hline \multirow{2}{*}{ Participants } & \multicolumn{2}{|c|}{ Males (n= 272) } & \multicolumn{2}{c|}{ Females (n = 208) } \\
\cline { 2 - 5 } & Mean & SD & Mean & SD \\
\hline Age & 13.64 & .519 & 13.50 & .560 \\
\hline Height (cm) & 157.88 & .143 & 153.19 & 12.570 \\
\hline Weight (kg) & 60.26 & 20.144 & 52.12 & 5.748 \\
\hline BMI & 24.42 & 9.885 & 22.36 & \\
\hline
\end{tabular}

Note: $\mathrm{n}$ = number of participants; $\mathrm{SD}=$ standard deviation; $\mathrm{BMI}=$ body mass index

\section{Study Design}

We used a non-experimental transversal design with correlational-causal approach. PA was included as the dependent variable, with three levels (low, moderate and high) the independent variables selected for this research were (a) psychological: importance given to PA; enjoyment of sedentary activities; confidence in reducing sedentary activities; (b) environmental: perceived environmental barriers toward PA; perceived neighborhood safety; and (c) social: social support towards PA; and social sedentarism.

\section{Instruments}

This study is based on the use of new technologies for collecting data. Specifically, all instruments were recorded and available on a free on-line system called Indares.com, created by the research team of the Centre of Kinantropology of Palacky University of Olomouc (the Czech Republic) and used within the framework of several international projects, including the International Physical Activity and Environmental Network (IPEN). Questionnaires available in the system and used for this study were:

1. International Physical Activity Questionnaire (IPAQ): the questionnaire consists of asking people how long (specifying total number of hours and minutes) they are engaged in different low, moderate and vigorous physical activities during a typical day/week. In addition, individuals were asked to report how long they are completely sedentary in a typical day. A brief description of the activities involved in each of the PA levels studied (including typical daily tasks such as gardening or housework) is provided for the items, to make it understandable. According to the questionnaire structure and guidelines, PA levels are described as follows: (a) low PA corresponds to any walking activities. An average score of 3.3 Metabolic Equivalents of Tasks (METs) is established for low PA; (b) moderate PA corresponds to activities that make people breath slightly harder than normal. An average score of 4.0 METs is established for moderate PA; and (c) vigorous PA refers to activities that make people breath much harder than normal. An average score of 6.0 METS is established for vigorous PA. Validity and reliability of this questionnaire were assessed for several countries, including Mexico [29]. They showed high reliability (Spearman's $\rho=.8$ ) and results on criterion validity comparable to other validation studies on self-reported $\operatorname{PA}(\rho=.3)$. 
2. Spanish version of the IPEN survey: this questionnaire was created by the research group of IPEN project and used in many published works worldwide [30,31]. A Spanish version of this instrument is available at the official webpage of IPEN project, and was already used in previous research [32]. IPEN survey is composed by several sections asking questions on different variables related to PA and sedentary behaviors. A description of each section, including sample items, score scales and reliability scores calculated for participants in this study is shown in Table 2.

Table 2. Description of the sections of International Physical Activity and Environmental Network (IPEN) questionnaires used in this study

\begin{tabular}{|c|c|c|c|}
\hline Section & Sample Items & Scores & $\begin{array}{c}\text { Cronbach's } \\
\text { alpha }\end{array}$ \\
\hline $\begin{array}{l}\text { Importance given } \\
\text { to PA }\end{array}$ & $\begin{array}{l}\text { PA would help me stay fit } \\
\text { I do not like the way PA and exercise make me feel }\end{array}$ & $\begin{array}{l}\text { Likert type } \\
1 \text { = strongly disagree } \\
4 \text { = strongly agree }\end{array}$ & .700 \\
\hline $\begin{array}{l}\text { Enjoyment of seden- } \\
\text { tary activities }\end{array}$ & $\begin{array}{l}\text { I think TV and computer/videogames are boring } \\
\text { I feel good about myself when I do well at my favorite } \\
\text { computer/videogame }\end{array}$ & $\begin{array}{l}\text { Likert type } \\
1 \text { = strongly disagree } \\
4 \text { = strongly agree }\end{array}$ & .660 \\
\hline $\begin{array}{l}\text { Perceived environ- } \\
\text { mental barriers }\end{array}$ & $\begin{array}{l}\text { It is difficult for me to be active in the local park or } \\
\text { streets/neighborhood near our home because there is no } \\
\text { choice of activities } \\
\text { It is difficult for me to walk or bike to my school because } \\
\text { there are no sidewalks or bike lanes }\end{array}$ & $\begin{array}{l}\text { Likert type } \\
1 \text { = strongly disagree } \\
4 \text { = strongly agree }\end{array}$ & .837 \\
\hline $\begin{array}{l}\text { Perceived ne- } \\
\text { ighborhood safety }\end{array}$ & $\begin{array}{l}\text { I feel safe crossing the streets in my neighborhood } \\
\text { The crime rate in my neighborhood makes it unsafe to go } \\
\text { on walks alone or with someone at night }\end{array}$ & $\begin{array}{l}\text { Likert type } \\
1 \text { = strongly disagree } \\
4=\text { strongly agree }\end{array}$ & .755 \\
\hline $\begin{array}{l}\text { Confidence in redu- } \\
\text { cing sedentarism }\end{array}$ & $\begin{array}{l}\text { I am sure I can turn off TV even when there is a program } \\
\text { that I enjoy } \\
\text { I am sure I can limit TV, video and computer videogames } \\
\text { to only } 2 \text { hours per day }\end{array}$ & $\begin{array}{l}\text { Likert type } \\
1 \text { = I am sure I cannot } \\
5 \text { = I am sure I can }\end{array}$ & .753 \\
\hline $\begin{array}{l}\text { Social support to- } \\
\text { wards PA }\end{array}$ & $\begin{array}{l}\text { How often do an adult in your household do physical } \\
\text { activity o play sports with you? } \\
\text { How often do your brothers/sisters or friends ask you to } \\
\text { walk or bike to school or to a friend's house? }\end{array}$ & $\begin{array}{l}\text { Likert type } \\
1=\text { never in a typical week } \\
5=\text { very often in a typical } \\
\text { week }\end{array}$ & .730 \\
\hline Social sedentarism & $\begin{array}{l}\text { How often do you sit and watch TV or play electronic } \\
\text { videogames (do not include time in exercise games like } \\
\text { Wii or Dance Dance Revolution) with: } \\
\text { Brothers/sisters } \\
\text { Friends }\end{array}$ & $\begin{array}{l}\text { Likert type } \\
1=\text { never in a typical week } \\
5=\text { every day in a typical } \\
\text { week }\end{array}$ & .812 \\
\hline
\end{tabular}

\section{Procedure}

Researchers firstly informed school principals and Physical Education (PE) teachers in each selected educational center about the aims and characteristics of the project. Directors of human resources in each school proceeded sending the information about the project to students' parents/guardians, who were asked to sign an informed consent allowing their kids to participate. Finally, measurements session dates were set according to the academic calendar of each school, to avoid creating any obstacles to the regular course of classes. During each session, researchers measured participants' height (tape) and weight (electronic scale). Students filled in the required questionnaires electronically, under the supervision of PE teachers and researchers from the project, who helped students with any doubt on the items and any technical problems with the system or Internet connection.

The current research was carried out within the framework of an international project supported by the European Union, and a national project supported by the National Council of Science and Technology of Mexico. Institutional review boards from both Palacky University in Olomouc (CZ) and Autonomous University of Nuevo León approved the research. 


\section{Data analysis}

All data uploaded to the system, including questionnaires responses and participants' general information, were exported as excel file, and then sent to an SPSS work sheet. Analyses of frequencies for each of the items and variables included were run to confirm that no mistakes were made while filling in the information. In addition, possible outliers for the variables of height, weight and height* weight were studied by means of standard scores and Mahalanobis D2 techniques. Analysis of distribution (skew and kurtosis), reliability, confirmatory factor analysis and correlations were executed for each dimension of the questionnaires. Finally, we used multiple linear regressions (MLR) to assess possible predictors of total weekly PA. Durbin-Watson test, outliers casewise diagnostics, Cook's distance, leverage points, collinearity diagnostic and analysis of tolerance and variance inflection factor (VIF), as well as distribution of residuals, homoscedasticity and linear relationship between dependent and independent variables were tested to confirm validity of the analysis.

\section{Results}

METs-minute/week were calculated according to the scoring protocol and the manual for interpreting IPAQ data and were used to assign participants to PA profiles as follows: students declaring at least three days of vigorous PA and a minimum of 1,500 METs, or seven or more days of any activity and a minimum of 3,000 METs, were labeled as high-PA profile (HPA). Those stating three or more days of at least 20 minutes of daily vigorous PA, or five or more days of at least 30 minutes daily walking or moderate PA, or seven or more days of any combination of activities and a minimum of 600 METs, were labeled as moderate-PA profiles (MPA). Finally, those not achieving any of the abovementioned conditions were labeled as low-PA profile (LPA). Table 3 shows results from IPAQ.

Table 3. Participants' Physical Activity profile and corresponding METs by gender

\begin{tabular}{|c|c|c|c|c|c|c|}
\hline \multirow{2}{*}{ Profile } & \multicolumn{3}{|c|}{$\begin{array}{c}\text { Males (n= 272) } \\
\text { METs-minute/week }\end{array}$} & \multicolumn{3}{c|}{$\begin{array}{c}\text { Females (n = 208) } \\
\text { METs-minute/week }\end{array}$} \\
\cline { 2 - 7 } & $\mathbf{n}$ & Mean & SD & n & Mean & SD \\
\hline Low level & 96 & 608.33 & 444.02 & 128 & 433.56 & 432.48 \\
\hline Moderate level & 96 & 1133.68 & 529.06 & 64 & 889.48 & 416.01 \\
\hline High level & 80 & 2941.08 & 837.02 & 16 & 2498.86 & 1033.77 \\
\hline
\end{tabular}

Note: $\mathrm{n}=$ number of participants; METs = metabolic equivalents of tasks; $\mathrm{SD}=$ Standard Deviation

LPA was composed by 224 students, representing $46.7 \%$ of the total sample. Within this profile, 96 were boys (42.9\%) and 128 were girls (57.1\%). Participants assigned to the MPA represented 33.3\% of the total sample, boys being $96(60 \%)$ and girls being 64 (40\%). Finally, 96 students (20\%) were included in the high-level group, as boys represented $83.3 \%(n=80)$ of this group whereas girls $16.7 \%(n=16)$.

MLR were run for boys and girls separately. Weekly METs was the dependent variable, while importance given to PA, enjoyment of sedentary activities, confidence in reducing sedentary behaviors, social support towards PA, social sedentarism, environmental safety and environmental barriers were the independent variables. Before running the analysis, normal distribution was assessed for the variables included in the model. Since weekly METs did not respect the assumption of normality (skewness =1.192), a square root transformation was executed. Normal distribution was confirmed for the transformed variable, which was included in the model as the dependent variable (skewness $=.288$ ).

\section{Boys MLR model}

The model was statistically significant for predicting weekly METs $\left(\mathrm{F}_{8,95}=2.463, \mathrm{p}=.018, \mathrm{R}^{2}=.402\right)$. The variables: importance given to PA, enjoyment of sedentary activities, and environmental barriers towards PA added statistical significance to the prediction $(\mathrm{p}<.05)$. Environmental safety, confidence reducing sedentarism, social sedentarism and social support did not fit significantly into the final model. Regression coefficients and standard errors are shown in Table 4 below. 
Table 4. Summary of multiple regression analysis for the sample of males

\begin{tabular}{|c|c|c|c|c|}
\hline Variable & Area & B & $\mathrm{SE}_{\mathrm{B}}$ & $\beta$ \\
\hline Intercept & & 99.328 & 18.371 & \\
\hline Importance given to physical activity & \multirow{3}{*}{ Psychological } & 12.711 & 4.509 & $.493^{* *}$ \\
\hline Enjoyment of sedentary activities & & -8.221 & 2.970 & $-.313^{* *}$ \\
\hline Confidence reducing sedentarism & & -2.691 & 2.257 & -.151 \\
\hline Social sedentarism & \multirow{2}{*}{ Social } & 1.429 & 1.512 & .122 \\
\hline Social support towards PA & & .135 & 1.802 & .008 \\
\hline Perceived environmental barriers & \multirow{2}{*}{ Environmental } & -7.040 & 2.518 & $-.354^{* *}$ \\
\hline Perceived environmental safety & & 4.405 & 3.611 & .144 \\
\hline
\end{tabular}

Note: ${ }^{* *} \mathrm{p}<.01 ; \mathrm{B}=$ unstandardized regression coefficient; $\mathrm{SE}_{\mathrm{B}}=$ standard error of the coefficient; $\beta=$ standardized coefficient

Validity of MLR was assessed by testing the following assumptions. Independence of residuals was confirmed by Durbin-Watson statistic of 1.855. Normal distribution of residuals was examined by means of histogram and P-P plot. Linear relationships and homoscedasticity were checked inspecting scatterplots and partial regression plots. No correlations between variables included in the model had high coefficient $(\mathrm{r}< \pm .456)$, as well as values for tolerance and VIF were good for the model (tolerance > .285; VIF < 3.508), rejecting possible multicollinearities. Presence of outliers was discarded by running casewise diagnostics of standardized residuals $(-1.73<$ SR $<$ 2.45), leverage points (Leverage <.15) and influential points (Cook's distance <.076).

\section{Girls MLR model}

The model was statistically significant for predicting weekly METs $\left(F_{8,91}=9.429, \mathrm{p}<.001, \mathrm{R}^{2}=.405\right)$. The variables: importance given to PA, enjoyment of sedentary activities, confidence reducing sedentarism, social sedentarism, social support and environmental barriers towards PA added statistical significance to the prediction $(\mathrm{p}<.05)$. Environmental safety did not fit significantly into the final model. Regression coefficients and standard errors are shown in Table 5 below.

Table 5. Summary of multiple regression analysis for the sample of females

\begin{tabular}{|c|c|c|c|c|}
\hline Variable & Area & B & $\mathrm{SE}_{\mathrm{B}}$ & $\beta$ \\
\hline Intercept & & 50.604 & 16.794 & \\
\hline Importance given to physical activity & \multirow{3}{*}{ Psychological } & 9.60 & 2.539 & $.336^{* *}$ \\
\hline Enjoyment of sedentary activities & & -6.033 & 2.919 & $-.171 *$ \\
\hline Confidence reducing sedentarism & & -10.339 & 1.936 & $-.552^{* *}$ \\
\hline Social sedentarism & \multirow{2}{*}{ Social } & -6.075 & 1.134 & $-.495 * *$ \\
\hline Social support towards PA & & 2.319 & 1.195 & $.174^{*}$ \\
\hline Perceived environmental barriers & \multirow{2}{*}{ Environmental } & -7.179 & 2.595 & $-.286^{* *}$ \\
\hline Perceived environmental safety & & 1.769 & 3.126 & .064 \\
\hline
\end{tabular}

Note: ${ }^{*} \mathrm{p}<.05 ;{ }^{* *} \mathrm{p}<.01 ; \mathrm{B}=$ unstandardized regression coefficient; $\mathrm{SE}_{\mathrm{B}}=$ standard error of the coefficient; $\beta=$ standardized coefficient

Tests were run for assessing the validity of MLR. Independence of residuals was confirmed by DurbinWatson statistic of 1.749. Normal distribution of residuals was examined by means of histogram and P-P plot. Linear relationships and homoscedasticity were checked inspecting scatterplots and partial regression plots. No correlations between variables included in the model had high coefficient $(\mathrm{r}< \pm .442)$, as well as values for tolerance and VIF were good for the model (tolerance > .474; VIF < 2.108), rejecting possible multicollinearities. Presence of outliers was discarded by running casewise diagnostics of standardized residuals $(-1.68<$ SR $<$ 2.21), leverage points (Leverage <.15) and influential points (Cook's distance <.073).

\section{Discussion}

The first aim of this study was to assess PA levels in a population of middle school students from the urban area of Monterrey (Mexico). For this reason, following the protocol and scoring rules of IPAQ questionnaire, we assigned participants to three different profiles of PA. HPA students are those participating in moderate to vigorous physical activities several times per week, thus they could be considered not at risk from the point of 
view of keeping a healthy, active lifestyle. In fact, in accordance with WHO recommendations for healthy PA, engaging in any moderate PA at least 30 minutes per day five times a week and any vigorous PA at least 20 minutes per day three times a week can be considered sufficient for attaining strong benefits in one's health state [33]. These requirements are widely met by persons in this profile. As results show, only $20 \%$ of the whole sample was assigned to HPA (83.3\% being boys, $16.7 \%$ being girls), which indicates that only a small proportion of students in our sample achieves active conducts that can be associated with health benefits. MPA profile includes persons who partially satisfy the requirements for healthy active behaviors, for instance they engage in vigorous PA 20 minutes per day three times a week, but they do not engage in sufficient moderate PA. According to WHO, MPA profile provides with lower gain in health parameters, for instance improving individuals' general fitness yet not determining changes in main physiological parameters associated with health [33,34]. In our study, 33.3\% of students were classified as MPA, with higher representation of boys (60\%) than girls (40\%). Finally, students in LPA do not fulfill any of the international recommendations for healthy PA. Thus, this group has higher risk of suffering from health problems in their adulthood. $46.7 \%$ of the sample in this research was found to have LPA profile, this group being composed by $42.9 \%$ of boys and $57.1 \%$ of girls. LPA profile boys were $35.8 \%$ of the overall sample of males, whereas out of the 208 female participants, $61.5 \%$ were assigned to this profile. Studies carrying out analysis of PA levels in populations with similar characteristics as ours obtained divergent results. Borracino et al. reported adolescents did not achieve the minimum recommendations for healthy PA, adding that there is a negative trend in engaging in PA through age [35]. Opposite outcomes were obtained by Cocca et al., who found out high levels of PA in a sample of students from middle school in Granada (Spain) [36]. In addition, in our study only 16 girls (7.7\% of the sample of females) are included in HPA, whereas 80 boys (29.9\%) are considered highly active. This proportions change in MPA and LPA profiles, the majority of girls being in the most at-risk group. These proportions are in line with previous literature on PA levels in boys and girls. Many studies have shown that boys are engaged in higher-intensity PA (such as competitive sports), while girls commonly choose lower-intensity activities, this occurrence being linked to social, cultural and psychological reasons [37].

The second aim of this study was to analyze models that could explain PA levels in boys and girls separately. Splitting the sample into two groups according to gender was necessary, as theory has largely demonstrated that this variable can represent a major covariate of PA, consequently affecting the results of MLR. Our intention was to describe the validity of models including psychological, social and environmental factors, as well as the weight of each of them in predicting PA. Hence, we decided to avoid possible contaminations of the model due to gender differences. Further, this allowed us to assess which factors were predominant in boys and girls, which could be important if we aim to design specific interventions for raising PA levels in the future. PA levels in both boys and girls were significantly positively predicted by the value they attribute to PA in their life, and negatively by the environmental impediments of the place they live as well as by their enjoyment in carrying out sedentary activities. Nonetheless, while the weight of these variables is similar in boys, for girls enjoying sedentary activities appears to be a less strong predictor. Social sedentarism (how frequently they are engaged in sedentary activities with friends or parents) and their confidence in being able to reduce the amount of time spent in sedentary activities are strong predictors for girls, but do not seem to be significant in boys. In addition, their PA levels are predicted positively by social support given by friends, siblings and parents, while none of the social factors considered in this study predicts PA in boys. Finally, motivation did not fit in any of the models generated by the analysis.

Literature confirms our findings about the importance of a context offering high possibilities of carrying out outdoor physical activity [38]. Also, studies have demonstrated that people being aware of the importance of exercising for their life, are usually more active than those who regard PA as not necessary [39]. Nonetheless, the relation between sedentarism and PA has yet not been clarified, as some authors found slightly significant negative correlation [5]. whereas others affirm that they do not affect each other [16]. Though, all those studies focus mainly on correlating time spent in PA and in sedentary activities, which could reasonably not be related as people can spend time in both activities during a typical day. Since in our study we take into consideration psychological aspects of sedentary behaviors, such as enjoyment, or individuals' confidence to be able to reduce the time they spend in such activities, that could explain why our results are not in line with previous literature. For instance, an aspect to contemplate is that confidence in reducing sedentary time appears to be a negative predictor of PA in girls. This could be interpreted as: "the surer they are of being able to change their sedentary behaviors whenever they want, the less they exercise". No studies were found in the existing literature that attempted to understand the relation between such psychological aspects of sedentarism and PA, thus deeper analysis and more research are required.

In line with literature, social factors were strong predictors for PA levels in girls [40]. However, in our study they were not significant factors in the prediction model for boys, this outcome being in contradiction with previous study. Although there is evidence that social influence drops down through age starting from 
adolescence [40], yet authors stress that it is strong in both boys and girls until late adolescence [41], Most of these studies consider only specific variables within the social influence, such as peers' influence, siblings' influence or parent's influence separately. This allows authors to execute a deeper analysis of certain social patterns, though they do not consider other aspects that could be influential. In this study parents', peers' and siblings' influence were considered as one and that could be a reason of discrepancy with existent literature. More detailed analysis of these variables could help us better understand the interaction between social context and PA.

\section{Conclusions}

PA levels in middle school students from Monterrey (Mexico) are in general low, consequently interventions should be planned to increase participation in health-related PA amongst youth. Understanding the psychological, social and environmental factors surrounding youth's PA or sedentary habits is fundamental to design suitable interventions that take into consideration the needs of a specific population. PA levels of boys in this study were significantly predicted by the importance they gave to exercising for their life, as well as by the enjoyment of carrying out sedentary activities and by perceived environmental barriers. These should be the main variables to work on when proposing in- or out-of-school PA programs, with the aim of producing significant changes towards more active conducts in boys. On the other hand, if we aim to raise PA levels and participation in physical activities in girls from this population, we should ponder social factors such as parents' and peers' support, who seem to play an important role in girls' decision to be active or not.

More research is required to better understand the interaction and weight of social support (especially in boys) on overall PA levels. In addition, in the future analyzing the mediating effect of variables such as motivation could help as create more complete behavioral models. An interesting issue emerging from this work is represented by psychological indicators related to sedentary behaviors, such as enjoyment or confidence.

\section{Disclosure and acknowledgements}

This paper was supported by the project "Exercise drop-out in Mexican youth and its relation with motivation, social environment, and weight increase", with ref. no: C00/425/13; and by the project "Support to create teams of excellence and intersectorial mobility at Palacky University of Olomouc", with ref. no: CZ.1.07/2.3.00/30.0004.

\section{References:}

1. World Health Organization. World health statistics. Geneva, CH: World Health Organization; 2014.

2. Biro FM, Wien M. Childhood obesity and adult morbidities. Am J Clin Nutr 2010; 91(5): 1499S-1505S. doi: 10.3945/ajcn.2010.28701B

3. Reilly JJ, Kelly J. Long-term impact of overweight and obesity in childhood and adolescence on morbidity and premature mortality in adulthood: systematic review. Int J Obes 2011; 35(7): 891-898. doi: 10.1038/ ijo.2010.222

4. Middelbeek L, Breda J. Obesity and sedentarism: Reviewing the current situation within the WHO European Region. Curr Obes Rep 2013; 2(1): 42-49. doi: 10.1007/s13679-013-0054-y

5. Janssen KAM, Oldehinkel AJ, Bonvanie IJ, Rosmalen JGM. An inactive lifestyle and low physical fitness are associated with functional somatic symptoms in adolescents. The TRAILS study. J Psychosom Res 2014; 76: 454-457. doi: 10.1016/j.jpsychores.2014.03.008

6. Siegel JM. Body image change and adolescent depressive symptoms. J Adolesc Res 2002; 17(1): $27-41$. doi: 10.1177/0743558402171002

7. Fröberg A, Raustorp A. Objectively measured sedentary behaviour and cardio-metabolic risk in youth: a review of evidence. Eur J Pediatr 2014; 173: 845-860. doi: 10.1007/s00431-014-2333-3

8. Pearson N, Braithwaite RE, Biddle SJH, van Sluijs EMF, Atkin AJ. Association between sedentary behaviour and physical activity in children and adolescents: a meta-analysis. Obes Rev 2014; 15: 666-675. doi: 10.1111/ obr.12188

9. Ekelund U, Luan J, Sherar LB, Esliger D, Griew P, Cooper A. Moderate to vigorous physical activity and sedentary time and cardiometabolic risk factors in children and adolescents. JAMA 2012; 307(7): 704-712. doi: 10.1001/jama.2012.156.

10. Stone MR, Faulkner GEJ. Outdoor play in children: association with objectively-measured physical activity, sedentary behavior and weight status. Prev Med 2014; 65: 122-127. doi: 10.1016/j.ypmed.2014.05.008 
11. Ortega F, Ruiz J, Castillo M, Sjöström M. Physical fitness in childhood and adolescence: a powerful marker of health. Int J Obes 2008; 32(1): 1-11. doi: 10.1038/sj.ijo.0803774

12. Wood F, Robling M, Prout H, Kinnersley P, Houston H, Butler C. A question of balance: a qualitative study of mothers' interpretations of dietary recommendations. Ann Fam Med 2010; 8(1): 51-57. doi: 10.1370/ afm.1072

13. De la Cerda P, Cervelló-Gimeno E, Cocca A, Viciana Ramírez J. Effects of an aerobic training program as complementary therapy in patients with moderate depression. Percept Mot Skills 2011; 112(3): 761-769. doi: 10.2466/02.15.PMS.112.3.761-769

14. Laitinen TT, Pahkala K, Magnussen CG, et al. Ideal cardiovascular health in childhood and cardiometabolic outcomes in adulthood. Circulation 2012; 125: 1971-1978. doi: 10.1161/CIRCULATIONAHA.111.073585.

15. Flodmark CE, Marcus C, Britton M. Interventions to prevent obesity in children and adolescents: a systematic literature review. Int J Obes 2006; 30: 579-589. doi:10.1038/sj.ijo.0803290

16. Bibiloni MDM, Pich J, Córdova A, Pons A, Tur JA. Association between sedentary behaviour and socioeconomic factors, diet and lifestyle among the Balearic Islands adolescents. BMC Public Health 2012; 12: 718. doi: 10.1017/S000711450999136X

17. Ardestani M, Niknami S, Hidarnia A, Hajizadeh E. Predictors of physical activity among adolescent girl students based on the social cognitive theory. J Res Health Sci 2015; 15(4): 223-227. Available from: http:// jrhs.umsha.ac.ir/index.php/JRHS/article/view/2112

18. Stamatakis E, Grunseit AC, Coombs N, et al. Association between socioeconomic position and sedentary behaviour in a large population sample of Australian middle and older-age adults: the social, economic, and environmental factor (SEEF) study. Prev Med 2014; 63: 72-80. doi: 10.1016/j.ypmed.2014.03.009

19. Stellino MB, Sinclair CD. Psychological predictors of children's recess physical activity motivation and behavior. Res Q Exerc Sport 2013; 84(2): 167-176. doi: 10.1080/02701367.2013.786159

20. Wójcicki TR, Szabo AN, White SM, Mailey EL, Kramer AF, McAuley E. The perceived importance of physical activity: association with psychosocial and health-related outcomes. J Phys Act Health 2013; 10 (3): $343-349$. Available from: http://www.ncbi.nlm.nih.gov/pmc/articles/PMC3856648/pdf/nihms510909.pdf

21. Vernadakis N, Zetou E, Derri V, Bebetsos E, Filippou F. The differences between less fit and overweight children on enjoyment of exergames, other physical activity and sedentary behaviours. Procedia Sco Behav Sci 2014; 152: 802-807. doi: 10.1016/j.sbspro.2014.09.324

22. Salmon J, Owen N, Crawford D, Bauman A, Sallis JF. Physical activity and sedentary behavior: a populationbased study of barriers, enjoyment, and preference. Health Psychol 2003; 22(2), 178-188. doi: 10.1037/02786133.22.2.178

23. Rhodes RE, Blanchard CM, Mark R. Confidence to overcome sedentary behavior time displacement for physical activity: demographic, occupational, and behavioral mediators. Psychol Health 2010; 25(Supplement 1), 315-316. Available from: http://web.a.ebscohost.com/ehost/pdfviewer/pdfviewer?vid=6\&sid=e648a60f8eee-4b96-8569-6884d08f4d10\%40sessionmgr4003\&hid=4206

24. Draper CE, Grobler L, Micksfield LK, Norris SA. Impact of social norms and social support on diet, physical activity and sedentary behaviour of adolescents: a scoping review. Child Care Health Dev 2015; 41(5): 654667. doi: $10.1111 /$ cch.12241

25. Lawman HG, Wilson DK. Association of social and environmental supports with sedentary behavior, light and moderate-to-vigorous physical activity in obese undeserved adolescents. Int J Behav Nutr Phys Act 2014; 11: 92. doi: 10.1186/s12966-014-0092-1

26. Dias DF, Loch MR, Ronque ERV. Perceived barriers to leisure-time physical activity and associated factors in adolescents. Cien Saude Colet 2015; 20(11), 3339-3350. doi: 10.1590/1413-812320152011.00592014

27. Huybrechts I, De Bourdeaudhuij I, De Henauw S. Environmental factors: opportunities and barriers for physical activity, and health eating. In: Moreno LA, Pigeot I, Ahrens W, eds. Epidemiology of Obesity in Children and Adolescents Volume 2. New York, NY: Springer; 2010. p. 391-418.

28. Datar A, Nicosia N, Shier V. Parent perceptions of neighborhood safety and children's physical activity, sedentary behavior, and obesity: evidence from a national longitudinal study. Am J Epidemiol 2013; 177(10): 1065-1073. doi: 10.1093/aje/kws353

29. Craig CL, Marshall AL, Sjöström M, et al. International physical activity questionnaire: 12-country reliability and validity. Med Sci Sports Exerc 2003; 35(8): 1381-1395. doi: 10.1249/01.MSS.0000078924.61453.FB

30. Cerin E, Sit CHP, Huang Y, Barnett A, Macfarlane D, Wong SSH. Repeatibility of self-report measures of physical activity, sedentary and travel behaviour in Hong Kong adolescents for the iHealth(H) and IPEN -Adolescent studies. BMC Pediatr 2014; 14: 142. doi: 10.1186/1471-2431-14-142 
31. Kerr J, Sallis J, Owen N, et al. Advancing science and policy through a coordinated international study of physical activity and built environments: IPEN methods. J Phys Act Health 2013; 10: 581-601. Available from: http://www.ipenproject.org/documents/publications_docs/Kerr_JPAH_IPEN_Methods.pdf

32. Aguinaga-Ontoso I, Orzanco Garralda R, Guillén-Grima F. Factors that influence on leisure time physical activity. Results from the IPEN (International Physical Activity and Environment Network) in Pamplona (Spain). Eur J Public Health 2012; 22(Suppl. 2): 131-132. Available from: http://eurpub.oxfordjournals.org

33. World Health Organization. Global recommendation on physical activity for health. Geneva, CH: World Health Organization; 2011.

34. Viciana-Ramírez J, Cocca A, Salinas-Martínez F. (2008). Effects of an Aerobic Capacity-Based program on cardiovascular risk factors in Spanish high schools. Circulation 2008; 117: e221. doi: 10.1161/ CIRCULATIONAHA.107.189344

35. Borracino A, Lemma $\mathrm{P}$, Iannotti RJ, et al. Socioeconomic effects on meeting physical activity guidelines: comparisons among 32 countries. Med Sci Sports Exerc 2009; 41(4): 749-756. doi: 10.1249/ MSS.0b013e3181917722

36. Cocca A, Liukkonen J, Mayorga-Vega D, Viciana J. Health-related physical activity levels in Spanish youth and young adults. Percept Mot Skills 2014; 118(1): 247-260. doi: 10.2466/10.06.PMS.118k16w1

37. Corder K, Van Sluijs EMF, McMinn AM, Ekelund U, Cassidy A, Griffin SJ. Perception versus reality awareness of physical activity levels of British children. Am J Prev Med 2010; 38(1): 1-8. doi: 10.1016/j.amepre.2009.08.025

38. Biddle SJH, Vrehm W, Verheijden M, Hopman-Rock M. Population physical activity behaviour change: a review for the European college of sport science. Eur J Sport Sci 2012; 12(4): 367-383. doi: 10.1080/17461391.2011.635700

39. Päivi M, Mirja H, Terttu P. Changes in physical activity involvement and attitude to physical activity in a 16year follow-up study among the elderly. J Aging Res 2010; 2010: 1-7. doi: 10.4061/2010/174290.

40. Deforche B, Van Dyck D, Verloigne M, De Bourdeaudhuij I. Perceived social and physical environment correlates of physical activity in older adolescents and moderating effect of self-efficacy. Prev Med 2010; 50: 524-529. doi: 10.1016/j.ypmed.2009.08.017

41. Kirby J, Levin KA, Inchley J. (2011). Parental and peer influences on physical activity among Scottish adolescents: a longitudinal study. J Phys Act Health 2011; 8: 785-793. Available from: http://www.research. ed.ac.uk/portal/files/10174232/Parental_and_Peer_Influence.pdf 